\title{
Distribution of ABO and Rh D blood groups in the population of Poonch district, Azad Jammu and Kashmir
}

M.N. Khan, ${ }^{1}$ I. Khaliq, ${ }^{2}$ A. Bakhsh, ${ }^{2}$ M.S. Akhtar ${ }^{3}$ and M. Amin-ud-Din ${ }^{2}$

$$
\begin{aligned}
& \text { توزع الزمر الدموية ABO وRHD بين سكان مقاطعة بونش وآزاد جامو وكشمير }
\end{aligned}
$$

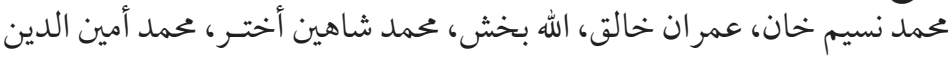



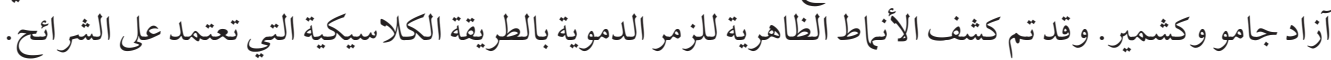

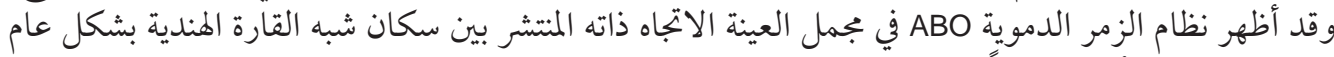



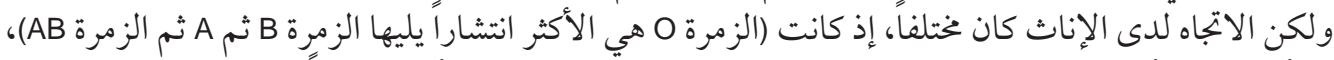

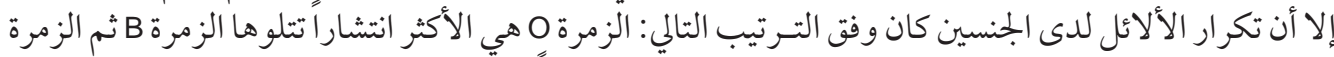



ABSTRACT We evaluated the distribution of $A B O$ and Rhesus (Rh) D blood groups in the population of Poonch district in Azad Jammu and Kashmir. The blood group phenotypes were detected by the classic slide method. The ABO blood group system in the total sample showed the same trend of prevalence as for the general Indian subcontinent $(B \geq O>A>A B)$. The same trend was found among males, but among females the order of prevalence was different $(O B>A>A B)$. However, the allelic frequencies in both sexes were in the order of $\mathrm{O}>\mathrm{B}>\mathrm{A}$. The Rh positive and negative distribution trend in both sexes was also similar.

\footnotetext{
Répartition des groupes sanguins $A B O$ et $R h$ D dans la population du district de Poonch (Azad Jammu-et-Cachemire)

RÉSUMÉ Nous avons évalué la répartition des groupes sanguins $A B O$ et Rhésus $(R h) D$ dans la population du district de Poonch (Azad Jammu-et-Cachemire). Les phénotypes de ces groupes ont été détectés par la méthode classique des frottis sur lame. Le système de groupe sanguin $A B O$ dans l'échantillon total présentait la même tendance de prévalence que celui du sous-continent indien en général $(B \geq O>A>A B)$. La même tendance était observée chez les hommes, alors que chez les femmes, l'ordre de prévalence était différent $(O \geq B>A>A B)$. Toutefois, les fréquences alléliques chez les deux sexes suivaient l'ordre $\mathrm{O}>\mathrm{B}>\mathrm{A}$. La tendance de répartition des $\mathrm{Rh}$ positif et négatif chez les deux sexes était également similaire.
}

${ }^{1}$ Department of Zoology, University of Azad Jammu and Kashmir, Muzaffarbad, Azad Jammu and Kashmir. ${ }^{2}$ Department of Biology, Government College, Dera Ghazi Khan, Pakistan (Correspondence to M. Amin-udDin: amin1158@hotmail.com).

${ }^{3}$ Department of Biology, Federal Government Degree College, Islamabad, Pakistan.

Received: 17/09/06; accepted: 03/12/06

المجلة الصحية لشرق المتوسط، منظمة الصحة العالمية، المجلد الخامس عشر، العدد با، 9 · ب 


\section{Introduction}

Since 1901, more than 20 distinct blood group systems have been characterized but the $\mathrm{ABO}$ and Rhesus (Rh) blood groups remain the most clinically important. Both these systems are useful in blood transfusion and organ transplantation. They are also well-defined genetic markers employed in population genetic and anthropological studies $[1,2]$. The distribution of these 2 blood groups has been repeatedly investigated in various populations all over the world during the last half-century. The frequencies exhibit considerable variation in different geographic locations, reflecting the underlying genetic and ethnic diversity of human populations [3].

In Azad Jammu and Kashmir, situated in the north-east corner of the Eastern Mediterranean Region, only 1 study on Rh blood groupings is available, an unpublished thesis [4]. To fill this gap in information, the present study was carried out to record the frequency of $\mathrm{ABO}$ and $\mathrm{Rh}$ blood groups in the population of Poonch district, Azad Jammu and Kashmir, with a view to generate data for health planners to utilize in future clinical, epidemiological and anthropological studies

\section{Methods}

Poonch district was divided into 2 parts during the Indo-Pakistan war of 1947-48; one remained with India and one became a part of Azad Jammu and Kashmir (a self-governing state under the auspices of Pakistan). Rawalakot is the headquarters of Poonch district in Azad Jammu and Kashmir. It has an area of $855 \mathrm{~km}^{2}$ and shares borders with Indian-controlled Kashmir in the east and Pakistan in the west. The population has remained intact and isolated because of the mountainous nature of the area. The total population of the district according to the 1998 census is $412000,80 \%$ from the Sudhan tribe, while the rest are mainly from the Pathan, Raja and Gujar tribes.

A sample of 3328 unrelated subjects (2920 males and 408 females) from different families and from different areas gave informed consent to participate in the study. The blood samples from the males were collected at various sites including the Combined Military Hospital in Rawalakot, United Hospital Rawalakot, the Boys High School and Degree College Rawalakot over a period of 3 years from June 2003 to June 2006. The blood samples from the females were collected from women attending $\mathrm{Dr}$ Amna Maternity Centre, Rawalakot. Local religious and cultural factors prevented sampling of women in this study.

Serological phenotyping was performed mainly by the procedure of forward typing in which a sample of blood was mixed with anti-A, anti-B and anti-D antisera (Plasmatec, Kent, United Kingdom). However, forf unclear results (158 cases) reverse typing (crossmatching) was performed for blood group confirmation. In this procedure, the person's serum was mixed with blood cells of a donor of known blood group to watch for agglutination. No attempt was made to further analyse subgroups.

The allelic frequencies and standard errors (SE) were calculated as per Hedrick's method [5]. The deviations between the distribution of observed and expected values in the Hardy-Weinberg equilibrium were also tested at the 5\% significance level.

\section{Results}

Overall, blood group B was the most prevalent $(36.6 \%)$, followed by groups $\mathrm{O}, \mathrm{A}$ and $\mathrm{AB}$. A similar trend was found among males but in females, blood group O (32.6\%) was 
the most prevalent, followed by $\mathrm{B}, \mathrm{A}$ and $\mathrm{AB}$ (Table 1). The difference in $\mathrm{A}, \mathrm{B}, \mathrm{O}$ and $\mathrm{AB}$ blood group prevalence between males and females was statistically significant $\left(\chi_{3}^{2}=18.129\right.$; $P<0.001)$.

In addition, in the total sample, the frequencies of $\mathrm{A}, \mathrm{B}$ and $\mathrm{O}$ alleles were calculated as 0.154 (SE 0.005), 0.249 (SE 0.006) and 0.591 (SE 0.007) respectively (Table 1 ). On comparison, the deviations between the distribution of observed data on ABO groups from expected values were not significant in the male sample $\left(\chi_{1}^{2}=3.062 ; P>0\right.$.05) but were significant in the female sample $\left(\chi_{1}^{2}=6.017 ; P<0.025\right)$ and in the total sample $\left(\chi_{1}^{2}=4.033 ; P \leq 0.05\right)$.

The distribution of $\mathrm{Rh}$ blood groups in males and females is shown in Table 2. At the $\mathrm{Rh}$ locus, $89.5 \%$ of the sample were $\mathrm{Rh}$ positive $(\mathrm{Rh}+))$. In addition, the frequency of $\mathrm{Rh}+$ among male and female participants was $89.8 \%$ and $87.8 \%$ respectively. The frequency of the $\mathrm{d}$ allele was calculated to be 0.350 (SE 0.023 ) in the male and female samples respectively (Table 2). -The difference between male and female samples at this locus was not statistically significant $\left(\chi_{1}^{2}=1.548 ; P>0.05\right)$.

On reverse typing of 158 subjects before blood transfusion, no incompatibility case was observed that confirmed the result of forward typing.

\section{Discussion}

In the present study, the ABO blood group typing in the total sample showed the same trend of prevalence as in the general Indian subcontinent $(\mathrm{B} \geq \mathrm{O}>\mathrm{A}>\mathrm{AB})$. The same trend was found among males but the order was different among females $(\mathrm{O} \geq \mathrm{B}>\mathrm{A}>\mathrm{AB})$. However, the allelic frequencies were in the order of $\mathrm{O}>$ $\mathrm{B}>\mathrm{A}$.

Statistically significant differences in the A, $\mathrm{B}, \mathrm{O}$ and $\mathrm{AB}$ blood group prevalence between males and females, along with the significant 


\begin{tabular}{|c|c|c|c|c|c|c|c|c|}
\hline \multirow[t]{3}{*}{$\overline{\text { Sex }}$} & \multicolumn{4}{|c|}{ Phenotype } & \multirow{3}{*}{$\begin{array}{c}\text { Total } \\
\text { No. }\end{array}$} & \multirow[t]{3}{*}{$\chi_{1}^{2}$} & \multicolumn{2}{|c|}{ Allelic frequency (SE) } \\
\hline & & & & & & & D & d \\
\hline & No. & $\%$ & No. & $\%$ & & & & \\
\hline Male & 2621 & 89.8 & 299 & 10.2 & 2920 & $1.548 ; P>0.05$ & $0.680(0.008)$ & $0.320(0.008)$ \\
\hline Female & 358 & 87.8 & 50 & 12.3 & 408 & & $0.650(0.023)$ & $0.350(0.023)$ \\
\hline Total & 2979 & 89.5 & 349 & 10.5 & 3328 & & $0.676(0.008)$ & $0.324(0.008)$ \\
\hline
\end{tabular}

$S E=$ standard error.

deviations between observed and expected values in females and the total sample, showed that the sample collected from the male population might be considered representative of the district population. The ABO blood group data collected from female visitors and patients at gynaecology wards or maternity centres might be non-representative because the sample may be skewed towards better educated and wealthier women who make routine visits to maternity centres during pregnancy, whereas women of the general population only use these facilities when facing gynaecological complications. Compared with the general population there was a $7.4 \%$ higher prevalence of blood group A among females recruited at maternity centres, which may indicate that females of blood group A are more susceptible to gynaecological problems.

The phenotypic and allelic frequencies of both $\mathrm{ABO}$ and $\mathrm{Rh}$ blood groups in the study area were notin completely consistent with neighbouring populations. For instance, blood group A was the most frequent in the northern neighbour populations of Nepal [6], Russian Federation [7] and Chitral [8]. The allelic frequencies for A, B and $\mathrm{O}$ in our study $(0.154,0.249$ and 0.591 respectively) were, however, closer to those of the Tibeten population $(0.1295,0.2544$ and 0.6152 ) but the allelic frequency of the $\mathrm{d}$ allele (0.324) differed from the Tibeten population (0.0572) [9]. Our findings also differed from those of a recent study in Arunachal Pradesh, India [10].

In the southern neighbour Pakistan, racial variation is found between provinces. The overall trend of $\mathrm{ABO}$ frequencies in our study was, however, very similar to the $\mathrm{B}$ $>\mathrm{O}>\mathrm{A}>\mathrm{AB}$ trend found in Punjab [11], but differed from trends in other provinces, such as $\mathrm{B}>\mathrm{A}>\mathrm{O}>\mathrm{AB}$ in Bannu, NorthWest Frontier Province [12], and $\mathrm{O}>\mathrm{B}>\mathrm{A}$ $>\mathrm{AB}$ in Sindh $[13,14]$. The allelic frequencies for A, B and O alleles in Sindh [13] and in Multan [15] also differed from our findings. But the trend of allelic frequencies $\mathrm{O}>\mathrm{B}>\mathrm{A}$ was similar in these studies.

In our population, the allelic frequency of $\mathrm{Rh}-(10.5 \%)$ agreed with other studies carried out in Bannu (10.8\%) [12] and Rawalpindi/Islamabad (8.7\%) [16], but differed from Punjab (2.8\%) [11] and even the Azad, Jammu and Kashmir population as whole (2.3\%) [4].

Our data shows that these allelic frequencies are unique and are not in total agreement with the previous studies. However, the allelic frequencies of $\mathrm{ABO}$ and $\mathrm{Rh}$ $\mathrm{d}$ are close to the population inhabiting the northern region of Pakistan, a finding that needs to be studied in more detail. 


\section{References}

1. Amin-ud-Din M et al. Serological study among the municipal employees of Tehran, Iran. Distribution of $\mathrm{ABO}$ and $\mathrm{Rh}$ blood groups. Haematology, 2004, 7(4):502-4.

2. Sigmon JM. Basic principles of the ABO and $\mathrm{Rh}$ blood group systems for hemapheresis practitioners. Journal of clinical apheresis, 1992, 7(3):158-62.

3. Cavalli-Sforza LL, Menozzi P, Piazza A. The history and geography of human genes. Princeton, New Jersey, Princeton University Press, 1994.

4. Rashid M. Gene frequency of $A B O$, blood groups in Azad Kashmir [MSc thesis]. Peshawar, Pakistan, Department of Botany, University of Peshawar, 1983.

5. Hedrick PW. Genetics of populations, 2nd ed. London, Jones and Bartlett, 2000.

6. Pramanik T, Pramanik S. Distribution of $\mathrm{ABO}$ and $\mathrm{Rh}$ blood groups in Nepalese medical students: a report. Eastern Mediterranean health journal, 2000, 6(1):1568.

7. Tomilin VV, Gurtovaia SV. Chastota vstrechaemosti antigenov sistemy ABO u nasekeniia Rossiiskoi Federatsii [The incidence of finding $\mathrm{ABO}$ system antigens in the population of the Russian Federation]. Sudebno-meditsinskaia ekspertiza, 1999, 42:16-8.

8. Bernhard W. Die Verteilung der ABOBlutgruppen und Haufigkeit des Rh-Faktors (D) bei verschiedenen ethnischen Gruppen im Hindukush (Kafiren, Kalash, Chitrali) [Distribution of ABO blood groups and incidence of $\mathrm{Rh}$ factor (D) in various ethnic groups in the Hindu Kush region (Kafirs, Kalash Chitrali)]. Anthropologischer Anzeiger, 1980, 37:251-4.

9. Tripathy $\mathrm{V} . \mathrm{ABO}$ and $\mathrm{Rh} \mathrm{D}$ polymorphism among Tibetans in India. Human biology, 2006, 78(2):229-33.

10. Krithika S, Maji S, Vasulu TS. Genetic heterogeneity among three Adi tribes of Arunachal Pradesh, India. Human biology, 2006, 78(2):221-7

11. Afzal M et al. A survey of blood groups. Journal of the Pakistan Medical Association, 1977, 27(11):426-8.

12. Khan MS et al. Prevalence of blood groups and $\mathrm{Rh}$ factor in Bannu region NWFP (Pakistan). Pakistan journal of medical research, 2004, 43(1):8-10.

13. Bhatti R, Shiekh DM. Variations of $A B O$ blood groups. Gene frequencies in the population of Sindh (Pakistan). Annals of King Edward Medical College, 1999. 5(3/4):328-31.

14. Hussain $A$ et al. Frequency of $A B O$ and $\mathrm{Rh}$ blood groups in the population of Balouchistan (Pakistan). Pakistan Armed Forces medical journal, 2001, 51(1):226.

15. Mian A, Faroog A. Distribution of ABO and $\mathrm{RH}$ blood group alleles in different populations of southern Punjab, Pakistan. Anthropologischer Anzeiger, 1999, 57(1):33-9.

16. Bhatti FA, Amin M. Spectrum of $A B O$ and D blood groups of donors at Rawalpindi/ Islamabad. Pakistan journal of pathology, 1996, 7(2):26-8. 